\title{
Adsorption of arsenites and arsenates from aqueous solutions by application of modified natural inorganic materials - a kinetic study
}

\begin{abstract}
Two commercially available adsorbents, white tuff from Strmos region and a material with a commercial name Zeofit obtained from Palanka region, were investigated as possible raw materials for adsorption of arsenites and arsenates from aqueous solutions. These raw materials were modified through chemical insertion of iron within the basic material structure and ionic substitution of calcium and magnesium ions with sodium ions in order to improve the sorptive and ion-exchange properties of studied raw materials. Obtained results from the experimental study of the adsorption of arsenic ions from simulated aqueous solutions suggest that the Zeofit material produced better results than the white tuff material, which showed satisfactory adsorption efficiency only at lower arsenic ions concentrations. Drinking water from the water supply system in Skopje was used for preparation of the studied arsenic ions solutions. Performed kinetic study and resulting kinetic models for both materials, generated a kinetic model of first order for the white tuff material, whereas the Zeofit material adsorption kinetics indicated a pseudosecond order.
\end{abstract}

Keywords: adsorption, adsorbent modification, modeling, kinetic study

\section{INTRODUCTION}

High quality drinking water supply is an essential precondition for human health, quality of life and any type of further development. Some analysis of the drinking water supply in Macedonia indicate a presence of arsenic, with significant quantities detected in surface and underground waters in the region of Kumanovo, eastern part of the country (Sveti Nikole, Probistip, Stip, Kocani, Vinica, Radovis and Strumica), Kavadarci and Gevgelija region. An increased presence of arsenic, and therefore a constant concern, is located in the geothermal water bodies in Kocani and the Kozuf region and some mineral water bodies and rivers, such as Bosavica, Dosnica, Konska River and Anska River. For the forthcoming period, this problem will become a growing concern issue.

Considering presented facts and concerning issues, general criteria imposed by the WHO [1] and EU Directives [2] are adopted in Macedonia and implemented within the legal regulative that defines the water supply quality, where the maximal permitted concentrations (MPC) regarding arsenic presence is $10 \mu \mathrm{g} / \mathrm{l}$ [3].

Arsenic represents a highly reactive element that occurs in several oxidation states $(-3,0,+3$ and +5$)$. Most common natural forms of arsenic are

Author's address: 1"Water Supply and Sewage", Public Enterprise, Skopje, Center for Sanitary Control, ${ }^{2}$ Faculty of Technology and Metallurgy, University "Ss. Cyril and Methodius", Skopje, R. Macedonia

Received for Publication: 12. 01. 2014.

Accepted for Publication: 19. 03. 2014. arsenite acids $\left(\mathrm{H}_{3} \mathrm{AsO}_{3}, \mathrm{H}_{3} \mathrm{AsO}_{3}{ }^{-}, \mathrm{H}_{3} \mathrm{AsO}_{3}{ }^{2-}\right)$, arsenate acids $\left(\mathrm{H}_{3} \mathrm{AsO}_{4}, \mathrm{H}_{3} \mathrm{AsO}_{4}^{-}, \mathrm{H}_{3} \mathrm{AsO}_{4}^{2-}\right)$, arsenates, arsenates, methyl-arsenic acid, dimethyl-arsenic acid, arsine etc. As (III) represents a strong acid agent that creates complexes with oxygen and nitrogen, whereas $A s(V)$ represents a mild acid agent that creates sulfide complexes. Inorganic arsenic forms are very common within water springs and is mobilization prone at oxidizing and reduction conditions like most of the metalloids. The two most present forms are the arsenite $\left(\mathrm{AsO}_{3}{ }^{3-}\right)$ and arsenate $\left(\mathrm{AsO}_{4}{ }^{3-}\right)$, or $\mathrm{As}(\mathrm{III})$ and $\mathrm{As}(\mathrm{V})$ respectively. $\mathrm{As}(\mathrm{V})$ or arsenate forms are $\mathrm{As}_{4}{ }^{3-}$, $\mathrm{HAsO}_{4}{ }^{2-}, \mathrm{H}_{2} \mathrm{AsO}_{4}^{-}$, whereas $\mathrm{As}(\mathrm{III})$ or arsenite forms are $\mathrm{As}(\mathrm{OH})_{3}, \mathrm{As}(\mathrm{OH})_{4}^{-}, \mathrm{AsO}_{2} \mathrm{OH}^{2-}$ и $\mathrm{AsO}^{3-}$. $\mathrm{As}(\mathrm{V})$ forms are dominant and stable in aerobic conditions, and As(III) forms are dominant and stable in mildly anaerobic environment, such as underground water bodies [4].

According to presented reasons, an arsenic removal is a necessity regarding drinking water treatment systems. Several removal techniques can be employed for arsenic removal, such as coagulation and flocculation with iron based salts [5]. This research is focused on application of a specific filter material that, along with the mechanical treatment of drinking water, possesses active arsenic adsorption properties at lower initial arsenic concentrations, present in previously treated effluents.

\section{MATERIALS AND METHODS}

Two commercially available materials were used within the experimental studies of this research: white opalized tuff from Strmos mine and Zeofit material obtained from Rankovce mine in 
Palanka region. The chemical characterization of the investigated raw materials as potential adsorbents is presented in Table 1.

Table 1 - Chemical characterization of used raw materials

\begin{tabular}{|l|c|c|}
\hline \multicolumn{1}{|c|}{ Parameter } & Strmos & Palanka \\
\hline $\mathrm{LOI}$ & 1.97 & 4.38 \\
\hline $\mathrm{Al}_{2} \mathrm{O}_{3}$ & 2.98 & 19.25 \\
\hline $\mathrm{CaO}$ & 0.18 & 4.29 \\
\hline $\mathrm{Cr}_{2} \mathrm{O}_{3}$ & 0.00 & 0.00 \\
\hline $\mathrm{Fe}_{2} \mathrm{O}_{3}$ & 0.10 & 5.00 \\
\hline $\mathrm{K}_{2} \mathrm{O}$ & 0.08 & 2.82 \\
\hline $\mathrm{MgO}$ & 0.00 & 0.70 \\
\hline $\mathrm{Mn}_{2} \mathrm{O}_{3}$ & 0.01 & 0.11 \\
\hline $\mathrm{Na}_{2} \mathbf{O}$ & 0.00 & 2.79 \\
\hline $\mathrm{P}_{2} \mathrm{O}_{5}$ & 0.02 & 0.22 \\
\hline $\mathrm{SO}_{3}$ & & \\
\hline $\mathrm{SiO}_{2}$ & 93.62 & 59.00 \\
\hline $\mathrm{SrO}$ & 0.02 & 0.12 \\
\hline $\mathrm{TiO}_{2}$ & 0.53 & 0.76 \\
\hline $\mathrm{ZnO}$ & 0.01 & 0.01 \\
\hline Total & 99.52 & 99.45 \\
\hline
\end{tabular}

The characterization of the investigated materials also included an analysis of mineral constituents, performed through XRD mineralogical analysis, is presented in Table 2.

Table 2 - XRD analysis of investigated raw materials

\begin{tabular}{|l|c|c|}
\hline \multicolumn{1}{|c|}{ Parameter } & Strmos & Palanka \\
\hline Quartz & 5.5 & 0.3 \\
\hline Cristobalite+Tridymite & 82 & 4.6 \\
\hline Feldspads & 4 & 56.1 \\
\hline $\mathrm{Fe}(\mathrm{OH})_{3}$ & & 5.4 \\
\hline Clays & 5.4 & 8.1 \\
\hline Calcite & & 1.5 \\
\hline Gypsum & 2.5 & - \\
\hline $\mathrm{TiO}_{2}$ & 0.6 & - \\
\hline Amorphous & $\star$ & 24 \\
\hline Total & 100 & 100 \\
\hline
\end{tabular}

The analysis of the obtained mineralogical composition suggests that the raw material from Strmos has a dominant $\mathrm{SiO}_{2}$ mass with an appropriate crystal composition (Quartz, Tridymite and Cristobalite) in crypto-crystal phase, whereas the Palanka material has a dominant feldspads mass with traces of free carbonates, free iron in forms of oxides and hydroxides, clay and a certain amount of amorphous phase $\mathrm{SiO}_{2}$.

A physical-chemical analysis of the composition of the drinking water from Skopje water supply system is given in Table 3. Presented values of the investigated parameters represent an average value of several analysis performed in the Center for Sanitary Control laboratories within the public enterprise "Water Supply and Sewage" Skopje. This water supply was used for preparation of experimental solutions.

Table 3 - Physical-chemical composition of used water

\begin{tabular}{|c|c|c|c|}
\hline \multirow{2}{*}{ Parameter } & \multicolumn{2}{|c|}{ MPC $^{*}$} & \multirow{2}{*}{ Result } \\
\hline & From & To & \\
\hline Temperature & & & 15.9 \\
\hline Odor & & 0.00 & None \\
\hline Taste & & & None \\
\hline Turbidity* & & 1.50 & 0.380 \\
\hline Conductivity* & & $\begin{array}{c}1,000.0 \\
0\end{array}$ & 539.000 \\
\hline $\mathrm{pH}^{*}$ & 6,50 & 9.50 & 7.350 \\
\hline $\begin{array}{l}\text { COD } \\
\text { (permanganate) }^{\star}\end{array}$ & & 8.00 & 2.210 \\
\hline Total hardness ${ }^{*}$ & & & 17.520 \\
\hline Dry residue $105^{\circ} \mathrm{C}$ & & $\begin{array}{c}1,000.0 \\
0\end{array}$ & 315.200 \\
\hline Alkalinity - p & & 0.00 & 0.000 \\
\hline Alkalinity - m & 30,00 & 120.00 & 59.160 \\
\hline Ammonia* $^{*}$ & & 0.50 & 0.000 \\
\hline Nitrites* & & 0.10 & 0.000 \\
\hline Nitrates* & & 50.00 & 6.920 \\
\hline Chlorides* & & 250.00 & 8.260 \\
\hline Sulphates & & 250.00 & 9.600 \\
\hline Silicates & & 20.00 & 11.070 \\
\hline Hydrocarbonates & & & 360.510 \\
\hline Manganese & & 0.05 & 0.000 \\
\hline Iron & & 0.20 & 0.020 \\
\hline Calcium & & 200.00 & 99.600 \\
\hline Magnesium & & 50.00 & 15.550 \\
\hline Sodium & & 200.00 & 7.600 \\
\hline Potassium & & 12.00 & 1.030 \\
\hline Chromium (total)* & & 0.05 & 0.010 \\
\hline Copper & & 0.10 & 0.000 \\
\hline Zinc & & 3.00 & 0.020 \\
\hline Aluminium & & 2.00 & 0.020 \\
\hline Nickel & & 0.02 & 0.010 \\
\hline
\end{tabular}

$M{ }^{*}$ - maximal permitted concentration according to the "Rulebook for water safety", published by the Official Gazette of R. Macedonia 46/2008

An operating solution with concentration of $1 \mathrm{~g} / \mathrm{l}$ was used for preparation of experimental solutions with concentrations of $20,30,40$ and $90 \mu \mathrm{g} / \mathrm{l}$ of As(III) and $\mathrm{As}(\mathrm{V})$ by utilization of the following salts [6], provided by FLUKA Riedel-de-Haen Germany: 
- Sodium arsenite $\left(\mathrm{As}^{+3}\right), \mathrm{NaAsO}_{2}$, p.a.

- Disodium meta-arsenate $\left(\mathrm{As}^{+5}\right)$, $\mathrm{Na}_{2} \mathrm{HAsO}_{4} \times 7 \mathrm{H}_{2} \mathrm{O}$, p.a.

\section{MODIFICATION}

An acid treatment was implemented for the raw material modification and for the chemical reaction in buffer solutions for application of an iron hydroxide layer. The iron hydroxide represents a macromolecule and the porous structure of the raw material is convenient for its insertion, as well as for the introduction of sodium ions as a neutralizing effect and as a component for the stabilization of the material. The procedures of acid-base treatment, especially regarding the insertion of the iron, are achievable even at room temperature, according to the literature data. On the other hand, best results are obtained at operating temperatures of $65-70{ }^{\circ} \mathrm{C}$. For this procedure, the following chemicals were used: $4 \% \mathrm{HCl}, 0.1 \mathrm{M} \mathrm{FeCl}_{3}$, acetate buffer with pH 3.6 (composed of $0.2 \mathrm{M} \mathrm{CH}_{3} \mathrm{COONa}$ and $0.2 \mathrm{M} \mathrm{CH}_{3} \mathrm{COOH}$ ), $4 \% \mathrm{NaOH}, 4 \% \mathrm{NaCl}$ and de-ionized water (for preparation of adequate solutions and material washing) [7-13].

The modified materials were subjected to a chemical analysis to determine the effect on the material and obtained results are presented in Table 4.

Table 4 - Chemical analysis of the modified material

\begin{tabular}{|l|c|c|}
\hline \multicolumn{1}{|c|}{ Parameter } & Strmos & Palanka \\
\hline $\mathrm{LOI}$ & 3.36 & 7.74 \\
\hline $\mathrm{Al}_{2} \mathrm{O}_{3}$ & 2.71 & 15.95 \\
\hline $\mathrm{CaO}$ & 0.14 & 2.96 \\
\hline $\mathrm{Cr}_{2} \mathrm{O}_{3}$ & 0.01 & 0.01 \\
\hline $\mathrm{Fe}_{2} \mathrm{O}_{3}$ & 4.18 & 9.32 \\
\hline $\mathrm{K}_{2} \mathrm{O}$ & 0.09 & 2.13 \\
\hline $\mathrm{MgO}$ & 0.00 & 0.38 \\
\hline $\mathrm{Mn}_{2} \mathrm{O}_{3}$ & 0.00 & 0.04 \\
\hline $\mathrm{Na}_{2} \mathrm{O}$ & 0.31 & 2.48 \\
\hline $\mathrm{P}_{2} \mathrm{O}_{5}$ & 0.16 & 0.14 \\
\hline $\mathrm{SO}_{3}$ & & \\
\hline $\mathrm{SiO}_{2}$ & 87.27 & 57.70 \\
\hline $\mathrm{SrO} \mathrm{y}_{2}$ & 0.07 & 0.09 \\
\hline $\mathrm{TiO}_{2}$ & 0.92 & 0.66 \\
\hline $\mathrm{ZnO}$ & 0.00 & 0.02 \\
\hline $\mathrm{Total}$ & 99.22 & 99.66 \\
\hline
\end{tabular}

The analysis was performed according to the same procedure and on the same instrument as in the case of the raw material using the analyzer XRF ARL 9900 XP Thermo ARL.

An AAS - Perkin Elmer AA 700/800 with a graphite furnace was used to determine the presence of arsenic within our experimental work at wavelength of $193.7 \mathrm{~nm}$. These analyses were conducted in the Center of sanitary control, Public enterprise "Water Supply and Sewage" Skopje.

\section{EXPERIMENTAL PROCEDURE}

Experiments were performed using magnetic stirrers on a boron-silicate laboratory glass. The experimental procedure was conducted as follows: $5 \mathrm{~g}$ of the material (fraction $<0.63 \mathrm{~mm}$ ) was added in $2 \mathrm{I}$ of solution with different initial concentrations of As, 20,30, 40 and $90 \mu \mathrm{g} / \mathrm{l}$ in the form of $\mathrm{As}^{3+}$ and $\mathrm{As}^{5+}$. Adsorption was performed at room temperature and $750 \mathrm{rpm}$ in a laboratory glass of 2000 $\mathrm{ml}$. At predefined time sequences, a $5 \mathrm{ml}$ sample was collected and filtrated through "black" filter paper. Then the sample was placed in a $10 \mathrm{ml}$ cuvette followed by $150 \mu \mathrm{l}$ concentrated $\mathrm{HNO}_{3}$ as conserver. Prepared samples were used to determine the total amount of arsenic.

\section{RESULTS AND DISCUSSION \\ Effect of initial arsenic concentration}

Figure 1 presents the dependency of arsenic removal percentage from the initial arsenic concentration in the solution at constant values for adsorption time. From presented results it can be concluded that modified materials from Palanka region have a similar efficiency of arsenic removal regardless of the arsenic form (III or V), whereas modified materials from Strmos tuff produce better results regarding arsenic removal at lower initial concentrations of arsenic within the analyzed samples.

\section{Effect of adsorption time}

Figure 2 presents the dependency of adsorbent capacity from the adsorption time at constant initial concentration of arsenic. The analysis of obtained results suggests that Palanka material produces almost equal adsorption capacity for $\mathrm{As}^{3+}$ and $\mathrm{As}^{5+}$, whereas Strmos material has a greater adsorption capacity for $\mathrm{As}^{5+}$. Regarding the adsorption kinetics, the Palanka material produced greater initial adsorption rate, followed by slower diffusive adsorption. The Strmos material, especially in the case of $\mathrm{As}^{5+}$ adsorption process, produces a relatively uniform adsorption rate. 


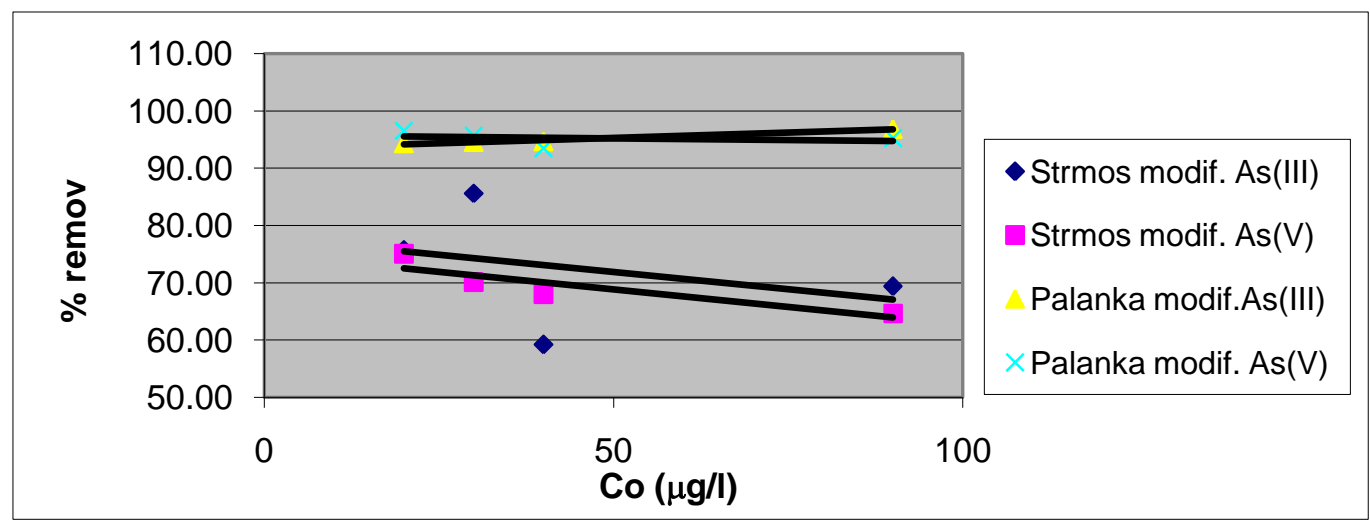

Figure 1 - Effect of initial arsenic concentration on the adsorption efficiency of $\mathrm{As}^{3+}$ and $\mathrm{As}^{5+}$ by hydrous ferric oxide modified materials $\left(C_{o}=20,30,40\right.$ and $90 \mu \mathrm{g} / \mathrm{l} ; \mathrm{pH}=7.35$; mass of adsorbent (fraction of $<0.63 \mathrm{~mm})=2.5 \mathrm{~g} / \mathrm{L} ; T=22^{\circ} \mathrm{C} ; t=420 \mathrm{~min}$ )

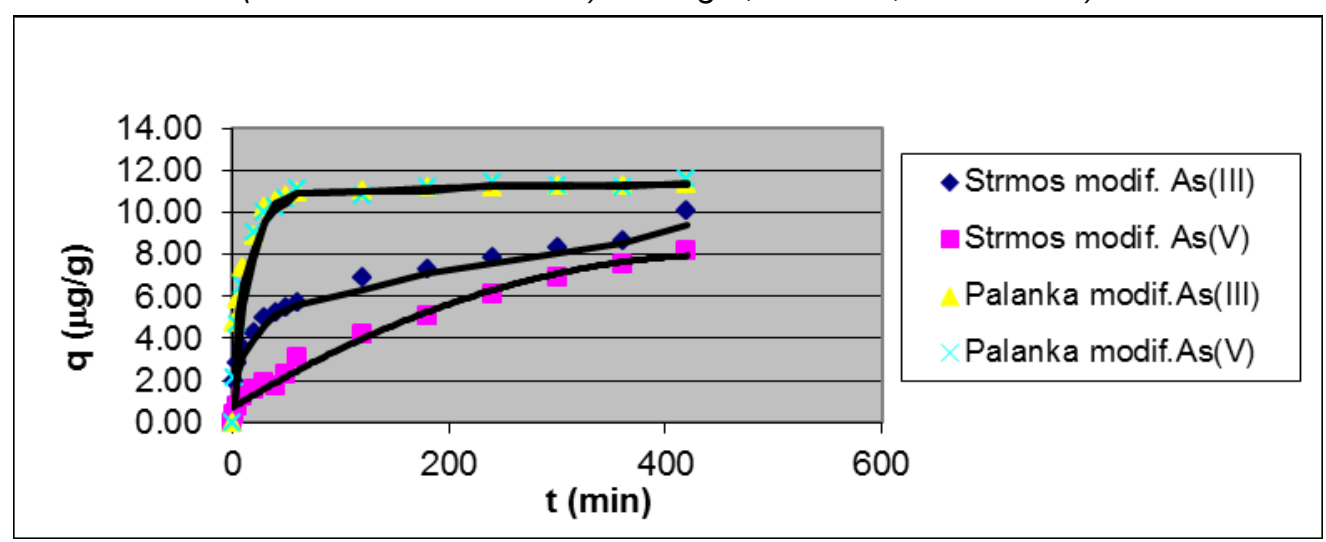

Figure 2 - Effect of initial arsenic concentration on the adsorption efficiency of $\mathrm{As}^{3+}$ and $\mathrm{As}^{5+}$ by hydrous ferric oxide modified materials $\left(C_{0}=30 \mu \mathrm{g} / \mathrm{l} ; \mathrm{pH}=7.35\right.$; mass of adsorbent (fraction of $<0.63 \mathrm{~mm})=2.5 \mathrm{~g} / \mathrm{L} ; T=22^{\circ} \mathrm{C} ; t=420 \mathrm{~min}$ )

\section{Kinetic models}

The basic empirical model that describes the kinetics of many processes as well as the adsorption kinetics represents a step function:

$$
R=k_{t} t^{m}
$$

Kinetics model of first order

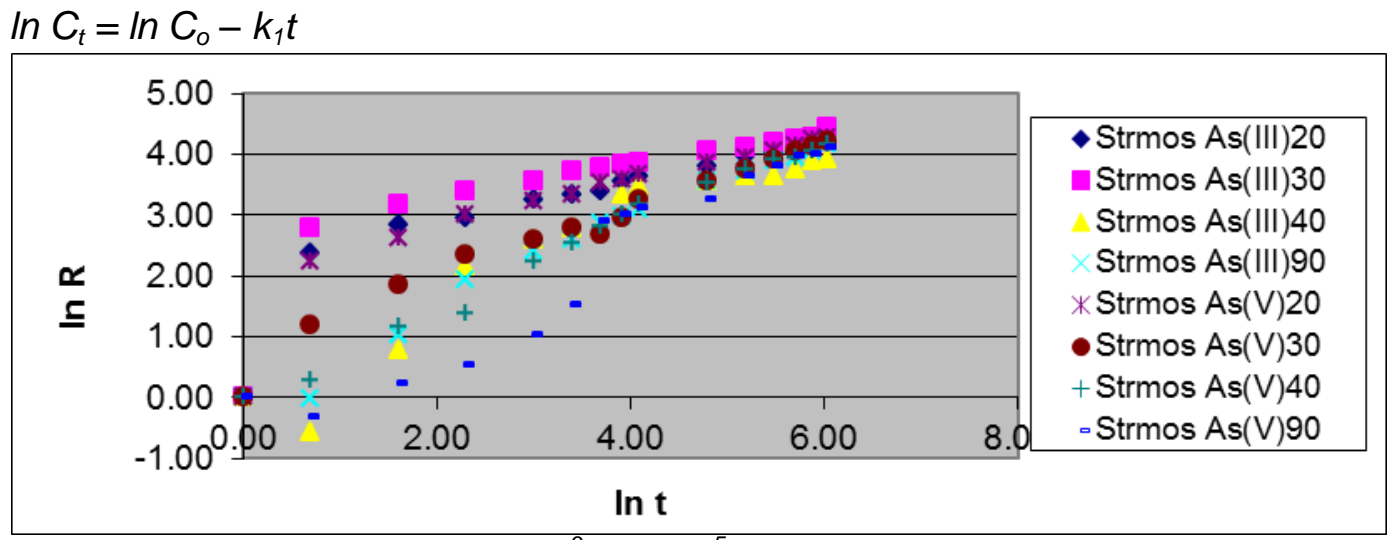

Figure $3-\ln R=f\left(\right.$ Int) for the kinetics of $\mathrm{As}^{3+}$ and $\mathrm{As}^{5+}$ adsorption on hydrous ferric oxide modified materials from Strmos $\left(C_{0}=20,30,40\right.$ and $90 \mu \mathrm{g} / \mathrm{l} ; \mathrm{pH}=7.35$; mass of adsorbent (fraction of $<0.63 \mathrm{~mm}$ ) $=2.5 \mathrm{~g} / \mathrm{L} ; T=22^{\circ} \mathrm{C} ; t=420 \mathrm{~min}$ ) 


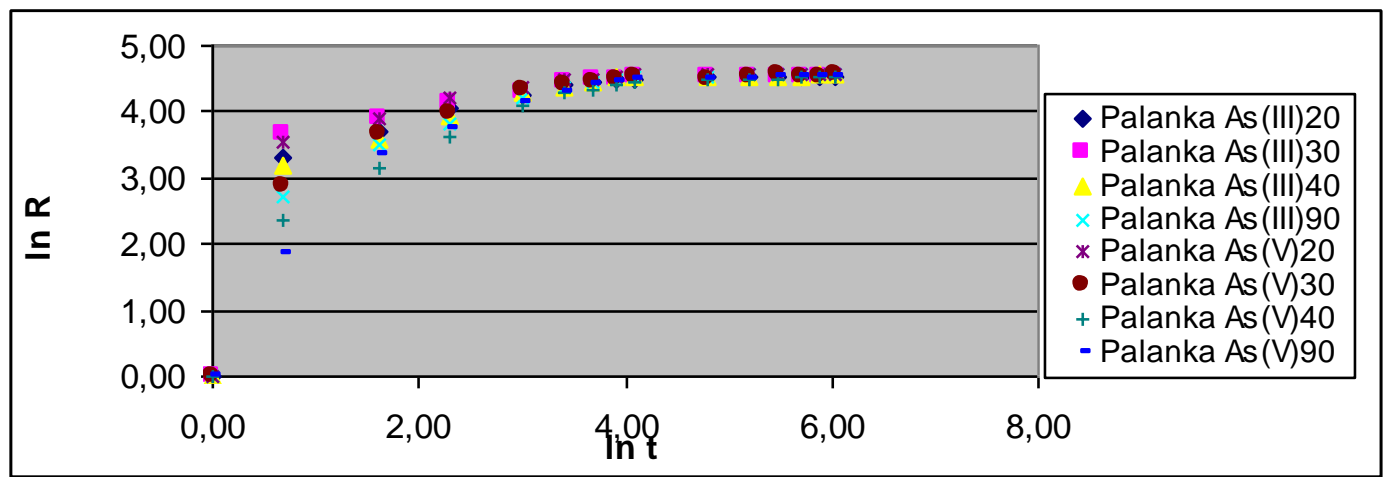

Figure $4-\ln R=f(\operatorname{Int})$ for the kinetics of $\mathrm{As}^{3+}$ and $\mathrm{As}^{5+}$ adsorption on hydrous ferric oxide modified materials from Palanka $\left(C_{o}=20,30,40\right.$ and $90 \mu \mathrm{g} / \mathrm{l} ; \mathrm{pH}=7.35$; mass of adsorbent (fraction of $<0.63 \mathrm{~mm}$ ) $=2.5 \mathrm{~g} / \mathrm{L} ; T=22^{\circ} \mathrm{C} ; t=420 \mathrm{~min}$ )

Kinetics model of pseudo-second order

$$
\frac{d q_{t}}{d t}=k_{\text {ads }}\left(q_{c}-q_{t}\right)^{2}, \quad t=0 ; q_{c}=0
$$

where $k_{a d s}$ is the constant of equilibrium state kinetics of pseudo-second order ( $\mathrm{g} / \mathrm{mgmin}), \mathrm{q}_{\mathrm{c}}$ is the adsorption capacity in equilibrium state $(\mathrm{mg} / \mathrm{g})$ and $q_{t}$ is quantity of adsorbed arsenic on the adsorbent surface area at adsorption time $\mathrm{t}(\mathrm{mg} / \mathrm{g})$.
After modification of the presented equation:

$$
\frac{1}{q_{t}}=\frac{1}{h}+\frac{1}{q_{e}} t
$$

where $h=k_{a d s} q_{e}^{2}$ is the initial adsorption rate (mg/g min).

The values for $q_{e}$ and $k_{a d s}$ are calculated from the slope and the cut-off from the linear graphical relation $t / q_{t}$ versa $t$.

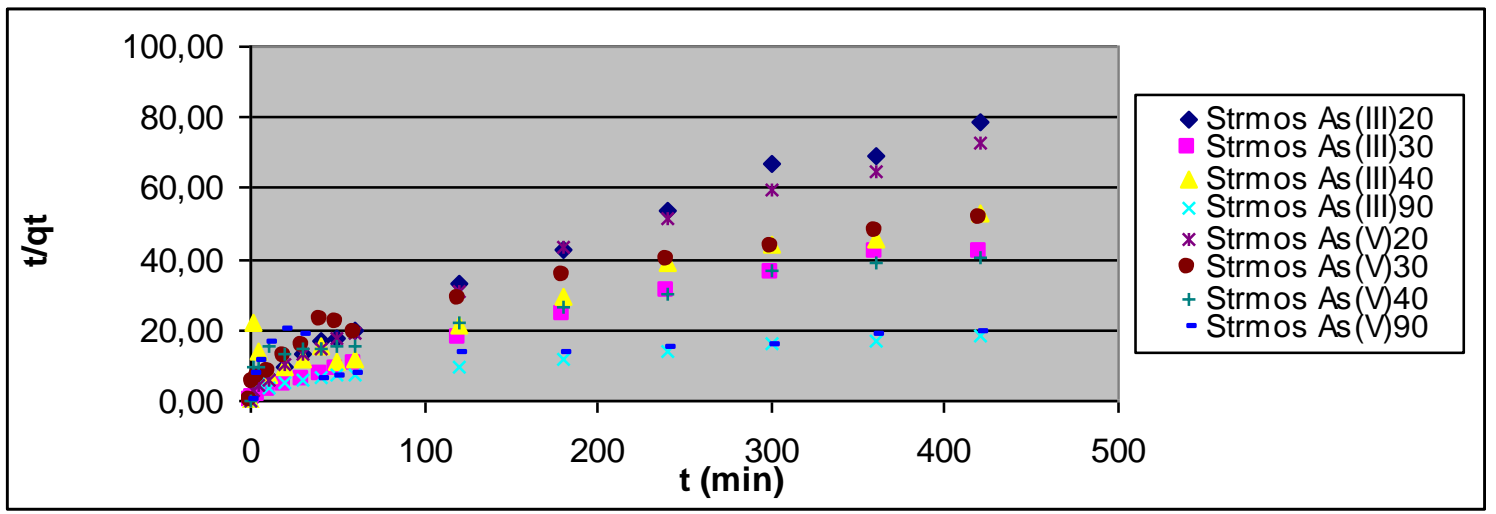

Figure 5 - Graphical relation $t / q_{t}$ versa $t$ for the $A s^{3+}$ and $A s^{5+}$ adsorption kinetics on hydrous ferric oxide modified materials from Strmos $\left(C_{o}=20,30,40\right.$ and $90 \mu \mathrm{g} / \mathrm{l} ; \mathrm{pH}=7.35$; mass of adsorbent (fraction of $<0.63 \mathrm{~mm}$ ) $=2.5 \mathrm{~g} / \mathrm{L} ; T=22^{\circ} \mathrm{C} ; t=420 \mathrm{~min}$ )

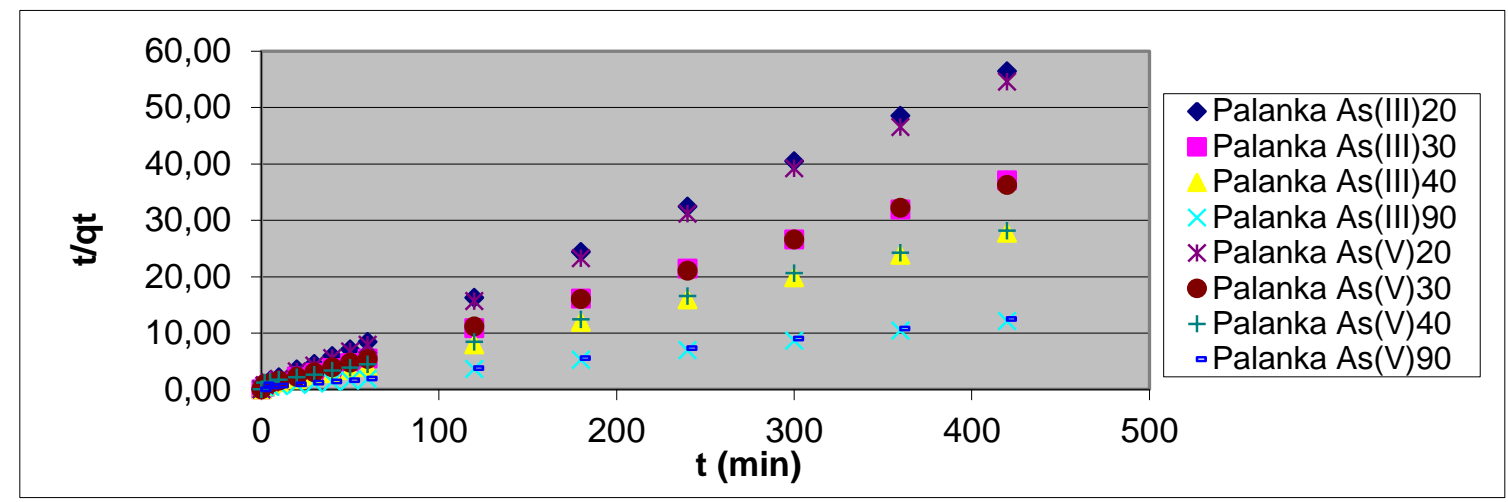

Figure 6 - Graphical relation $t / q_{t}$ versa $t$ for the $A s^{3+}$ and $A s^{5+}$ adsorption kinetics on hydrous ferric oxide modified materials from Palanka $\left(C_{o}=20,30,40\right.$ and $90 \mu \mathrm{g} / \mathrm{l} ; \mathrm{pH}=7.35$; mass of adsorbent (fraction of $<0.63 \mathrm{~mm}$ ) $=2.5 \mathrm{~g} / \mathrm{L} ; T=22^{\circ} \mathrm{C} ; t=420 \mathrm{~min}$ ) 
Table 5 - Calculated coefficient values for the first order model equation for the Strmos material

\begin{tabular}{|c|c|c|c|c|c|c|}
\cline { 2 - 7 } \multicolumn{1}{c|}{} & \multicolumn{3}{c|}{ Step 1 (0-10 min) } & \multicolumn{3}{c|}{ Step 2 (10-420 min) } \\
\hline $\mathrm{Strmos}_{\mathrm{As}}^{3+} 20$ & $\mathbf{m}$ & $\mathbf{K}_{\mathbf{T}}$ & $\mathbf{R}^{2}$ & $\mathbf{m}$ & $\mathbf{K}_{\mathbf{T}}$ & $\mathbf{R}^{\mathbf{2}}$ \\
\hline $\mathrm{As}^{3+} 30$ & 1.6981 & -0.3624 & 0.8107 & 0.3244 & 0.3519 & $\mathbf{0 . 9 8 9 8}$ \\
\hline $\mathrm{As}^{3+} 40$ & 1.8883 & -0.2711 & 0.7766 & 0.2508 & 0.4529 & $\mathbf{0 . 9 8 7 1}$ \\
\hline $\mathrm{As}^{3+} 90$ & 0.5391 & -0.4713 & 0.4162 & 0.4445 & 0.1183 & $\mathbf{0 . 9 1 3 7}$ \\
\hline $\mathrm{As}^{5+} 20$ & 1.5713 & -0.7690 & 0.8097 & 0.5899 & -0.1949 & $\mathbf{0 . 9 9 4 7}$ \\
\hline $\mathrm{As}^{5+} 30$ & 1.1210 & -0.3839 & 0.8020 & 0.3362 & 0.3508 & $\mathbf{0 . 9 9 4 3}$ \\
\hline $\mathrm{As}^{5+} 40$ & 0.7321 & -1.0841 & 0.9383 & 0.5384 & -0.0218 & $\mathbf{0 . 9 7 5 4}$ \\
\hline $\mathrm{As}^{5+} 90$ & 0.1730 & -0.7945 & 0.9567 & 0.6788 & -0.7435 & $\mathbf{0 . 9 6 4 4}$ \\
\hline
\end{tabular}

Table $5 a$ - Calculated coefficient values for the first order model equation for the Palanka material

\begin{tabular}{|c|c|c|c|c|c|c|}
\cline { 2 - 7 } \multicolumn{1}{c|}{} & \multicolumn{3}{c|}{ Step 1 (0-10 min) } & \multicolumn{3}{c|}{ Step 2 (10-420 min) } \\
\hline Palanka & $\mathbf{m}$ & $\mathbf{K}$ & $\mathbf{R}_{\mathbf{T}}$ & $\mathbf{m}$ & $\mathbf{K}_{\mathbf{T}}$ & $\mathbf{R}^{\mathbf{2}}$ \\
\hline $\mathrm{As}^{3+} 20$ & 2.1936 & -0.1897 & 0.7634 & 0.0972 & 0.6032 & 0.7050 \\
\hline $\mathrm{As}^{3+} 30$ & 2.3012 & -0.1212 & 0.7215 & 0.0857 & 0.6112 & 0.6743 \\
\hline $\mathrm{As}^{3+} 40$ & 2.1215 & -0.2069 & 0.7556 & 0.1197 & 0.5926 & 0.6310 \\
\hline $\mathrm{As}^{3+} 90$ & 2.1023 & -0.3449 & 0.8582 & 0.1500 & 0.5755 & 0.6836 \\
\hline \hline $\mathrm{As}^{5+} 20$ & 2.3135 & -0.1487 & 0.7482 & 0.0721 & 0.6216 & 0.6633 \\
\hline $\mathrm{As}^{5+} 30$ & 2.2012 & -0.3150 & 0.8526 & 0.1065 & 0.5998 & 0.6533 \\
\hline $\mathrm{As}^{5+} 40$ & 0.8521 & -2.0000 & 0.9994 & 0.1848 & 0.5476 & 0.7162 \\
\hline $\mathrm{As}^{5+} 90$ & 2.0476 & -0.8074 & 0.9797 & 0.1575 & 0.5662 & 0.6918 \\
\hline
\end{tabular}

Presented results in Table 5 and Table 5a suggest that the Strmos material adsorption produces a better fit regarding the first order kinetics in the diffusion stage than the Palanka material.

Table 6 - Calculated coefficient values for the pseudo-second order model equation for the Strmos material

\begin{tabular}{|c|c|c|c|c|}
\hline \multirow{2}{*}{ Strmos } & \multicolumn{4}{|c|}{ Step 1 (0-420 min) } \\
\hline & $q_{e}$ & $\mathrm{~K}_{\mathrm{ads}}$ & $h=k_{\text {ads }} q_{e}{ }^{2}$ & $\mathbf{R}^{2}$ \\
\hline $\mathrm{As}^{3+} 20$ & 5,3792 & 0,213529 & 6,1787 & 0.9798 \\
\hline $\mathrm{As}^{3+} 30$ & 9,4877 & 0,030827 & 2,7749 & 0.9782 \\
\hline $\mathrm{As}^{3+} 40$ & 9,2764 & 0,106055 & 9,1263 & 0.9069 \\
\hline $\mathrm{As}^{3+} 90$ & 27,5482 & 0,005866 & 4,4515 & 0.9297 \\
\hline$\overline{\mathrm{As}^{5+} 20}$ & \begin{tabular}{c|}
5,8411 \\
\end{tabular} & 0,189137 & "6,4531 & 0.9766 \\
\hline $\mathrm{As}^{5+} 30$ & 9,1075 & 0,125986 & 10,4500 & 0.9004 \\
\hline $\mathrm{As}^{5+} 40$ & 12,5471 & 0,066373 & 10,4490 & 0.9182 \\
\hline $\mathrm{As}^{5+} 90$ & 46,7290 & 0,004535 & 9,9018 & 0.2628 \\
\hline
\end{tabular}

Table 6a-Calculated coefficient values for the pseudo-second order model equation for the Palanka material

\begin{tabular}{|c|c|c|c|c|}
\cline { 2 - 5 } \multicolumn{1}{c|}{} & \multicolumn{4}{c|}{ Step 1 (0-420min) } \\
\hline Palanka & $\mathbf{q}_{\mathbf{e}}$ & $\mathbf{K}$ ads & $\mathbf{h}=\mathbf{k}_{\text {ads }} \mathbf{q}_{\mathbf{e}}{ }^{2}$ & $\mathbf{R}^{\mathbf{2}}$ \\
\hline $\mathrm{As}^{3+} 20$ & 7,5245 & 0,009843 & 0,5573 & $\mathbf{0 . 9 9 9 9}$ \\
\hline $\mathrm{As}^{3+} 30$ & 11,4025 & 0,002299 & 0,2989 & $\mathbf{0 . 9 9 9 9}$ \\
\hline $\mathrm{As}^{3+} 40$ & 15,3374 & 0,001301 & 0,3061 & $\mathbf{0 . 9 9 9 7}$ \\
\hline $\mathrm{As}^{3+} 90$ & 35,4610 & 0,000164 & 0,2061 & $\mathbf{0 . 9 9 9 6}$ \\
\hline $\mathrm{As}^{5+} 20$ & 7,7700 & 0,005842 & 0,3527 & $\mathbf{0 . 9 9 9 9}$ \\
\hline $\mathrm{As}^{5+} 30$ & 11,5741 & 0,003565 & 0,4776 & $\mathbf{0 . 9 9 9 4}$ \\
\hline $\mathrm{As}^{5+} 40$ & 34,4828 & 0,000248 & 0,2954 & $\mathbf{0 . 9 9 8 2}$ \\
\hline $\mathrm{As}^{5+} 90$ & 15,2672 & 0,002984 & 0,6955 & $\mathbf{0 . 9 9 9 2}$ \\
\hline
\end{tabular}

Based on the obtained results regarding the model coefficients for the pseudo-second order kinetics, the Palanka material adsorption process produces a better fit to the experimental data than the Strmos material.
Legend:

$\mathbf{R}$ - adsorption efficiency (\%)

q - adsorption capacity $(\mu \mathrm{g} / \mathrm{g})$

$\mathbf{q}_{\mathbf{c}}$ - equilibrium state amount of adsorbed arsenic $(\mu \mathrm{g} / \mathrm{g})$ 
$\mathbf{q}_{\mathbf{t}}$ - amount of adsorbed arsenic on the adsorbent surface at time $\mathrm{t}(\mu \mathrm{g} / \mathrm{g})$.

$\mathbf{t}$ - adsorption (contact) time (min),

$q_{e}-$ Boundary adsorption capacity of the solid $(\mu \mathrm{g} / \mathrm{g})$

$\mathbf{h}$ - initial adsorption rate $(\mu \mathrm{g} / \mathrm{g} \min )-\mathrm{h}=\mathrm{k}_{\mathrm{ads}} \mathrm{q}_{\mathrm{e}}{ }^{2}$

$\mathbf{C}^{*}$ - arsenic equilibrium concentration in the solution $(\mu \mathrm{g} / \mathrm{L})$

m - model constant

$\mathbf{K}_{\mathbf{t}}-$ model constant

$\mathbf{K}_{\mathbf{a d s}}$ - constant of the equilibrium state reaction rate of pseudo-second order ( $\mu \mathrm{g} / \mathrm{gmin})$

\section{CONCLUSIONS}

- Modified materials from Palanka region have a similar efficiency of arsenic removal regardless of the arsenic form (III or V) and initial concentration, whereas modified materials from Strmos tuff produce better results regarding arsenic removal at lower initial concentrations of arsenic within the analyzed samples.

- Regarding the adsorption kinetics, the Palanka material produced greater initial adsorption rate, followed by slower diffusive adsorption. The Strmos material, especially in the case of $\mathrm{As}^{5+}$ adsorption process, produces a relatively uniform adsorption rate.

- The Strmos material adsorption produces a better fit regarding the first order kinetics in the diffusion stage than the Palanka material

- The Palanka material adsorption process produces a better fit regarding the pseudo-second order kinetics than the Strmos material

\section{REFERENCES}

[1] WHO (World Health Organization).IGuidelines for Drinking Water Quality. Third edition Recommendations, Vol 1; Geneva:2004
[2] Council Directive EU 98/83/EC for the quality of water intended for human consumption. Brussels; 1983

[3] "Rulebook for water safety", published by the Official Gazette of R. Macedonia 46/2008

[4] WHO (World Health Organization), Environmental Health Criteria, 18: Arsenic, World Health Organization, Geneva 1981

[5] D.Dimitrovski and Z.Bozinovski, (2012) Arsenic removal through coagulation and flocculation from contaminated water in Macedonia, Zaštita materijala 53 (1) $45-52$

[6] D. Dimitrovski and Z.Bozinovski, (2011) Adsorption of Nickel(II)lons Aqueos Solutions Using Alumina, Quality of Life, 2(3-4) 57-65

[7] D.Dimitrovski and Z.Bozinovski, (2011) Batch Adsorption of Nickel from Aqueous Solution by Natural Zeolite-Equilibrium study, J.Chem.Chem. Eng. 5 (2) 528-534

[8] G.Montes-Hernandez et al, (2009) Removal of oxyanions from syntetic wastewater via carbonation process of calcium hydroxide: Applied and fundamental aspects. J.Of Hazardous Materials 166 (10) 788-795

[9] R.Ch. Vaishya and S.K.Gupta (2011) Optimization of oxide process on quartz sand for arsenic(III) removal from groundwater Journal of Water Supply Research and Technology Vol.60 (2) 109-120

[10] P. Kumar et al, (2007) Surface modified zeolite -A for sequestration of arsenic and chromium anions Curent Science, 92(4) 512-517

[11] M. Hobuda-Stanic et al Quality of groundwater in Eastern Croatia. The problem of arsenic pollution. 9.Int.Conf. Rhodes Greece, 2005

[12] M.Hobuda-Stanic et al., (2008) Arsenite and arsenate sorption by hydrous ferric oxide/polymeric material, Desalination 229(1) 1-9

[13] E.Chmielevska, (2003), Adsorption of Arsenate and Chromate From Waters on Hydrophobized Zeolitic Media, Turk J.Chem 27 (10) 639-648

\section{ИЗВОД \\ АДСОРПЦИЈА АРСЕНИТА И АРСЕНАТА ИЗ ВОДЕНИХ РАСТВОРА ПРИМЕНОМ МОДИФИКОВАНИМ ПРИРОДНИХ НЕОРГАНСКИХ МАТЕРИЈАЛА-КИНЕТИЧКА СТУДИЈА}

Два комерцијално доступна адсорбента, бели туфр из региона Стрмош и материјала са комерцијалним именом Зеофит добијеним из региона Паланке, испитивани су као могућа сировина за адсорпцију арсенита и арсената из водених раствора. Ове сировине су модификоване хемијским убацивањем гвожђа у основну структуру материјала и јонском изменом калцијума и магнезијума са натријум јона у циљу побољшања сорпционе и јоноизмењивачке особине испитиваног материјала. Добијени резултати експерименталног истраживања за адсорпцију арсенових јона из моделних водених раствора сугеришу да Зеофит показује боље резултате од материјала бели туф, који је показао задовољавајуће резултате само при нижим концентрацијама арсена. Извршена кинетичка студија за оба материјала дају кинетички модел из првог реда за материјал бели туф, док за Зеофитом добија се кинетички модел из псеудо - другог реда.

кључне речи: адсорпција, модифицирање адсорбента, моделовање, кинетичка студија

Оригинални научни рад

Примљено за публиковање: 12. 01. 2014.

Прихваћено за публиковање: 19. 03. 2014. 